УДК 631.53.04:633.112.1, DOI 10.31210/visnyk2018.02.04

(C) 2018

Ярчук І. І., доктор сільськогосподарських наук, професор, Мельник Т. В., аспірант

(науковий керівник - доктор сільськогосподарських наук, професор I. I. Ярчук)

Дніпропетровський державний аграрно-економічний університет

\title{
ПОПЕРЕДНИКИ ТА СРОКИ СІВБИ ПШЕНИЦІ ТВЕРДОЇ ОЗИМОЇ
}

\section{Рецензент - доктор сільськогосподарських наук, професор А. Д. Гирка}

Наведено результати трьохрічних польових досліджень з дослідження впливу попередників та строків сівби на формування продуктивності пшеницею твердою озимою сорту Континент в умовах північного Степу України. Описано вплив строку сівби та попередника на ріст і розвиток рослин, їх перезимівлю та врожайність пшенииі твердої озимої. Наведено рекомендації щзодо підвищення якості перезимівлі пшениці твердої озимої. За чотирирічними даними зроблено висновки щуодо врожайності пшениці твердої озимої залежно від попередника, рівня мінерального живлення та строку сівби.

Ключові слова: пшениця тверда озима, попередники, строки сівби, перезимівля, врожайність.

Постановка проблеми. Під посівами пшениці м'якої озимої зайняті майже всі площі озимих культур, в той час як пшениця тверда озима практично не зустрічається в багатьох областях із відносно сприятливими умовами іï вирощування. На теперішній час харчова промисловість не забезпечена повною мірою зерном твердої пшениці вітчизняного виробництва [3]. Підраховано, що потреба України в зерні пшениці твердої сягає 1 млн тонн. Останнім часом з'явились високопродуктивні сорти пшениці твердої озимої [4], однак вони все ж мають притаманну даному виду низьку зимостійкість і значно поступаються за цим показником сортам пшениці м'якої. Тому необхідно дослідити вплив основних елементів технології вирощування та визначити методи досягнення максимальної врожайності за різних умов вирощування пшениці твердої озимої.

Аналіз останніх досліджень і публікацій, у яких започатковано розв'язання проблеми. За багаторічними даними, в Степу в середньому за рік пересівається четверта частина посівів пшениці озимої [2]. Це спричинено не лише несприятливими погодними умовами осіннього та зимового періодів, але і прорахунками в технології вирощування пшениці.

Найбільш впливовим технологічним елементом $€$ вибір строку сівби залежно від грунтово- кліматичних умов, адже строк сівби найбільше регулює ступінь розвитку рослин перед початком зимівлі і, відповідно, рівень стійкості до несприятливих чинників. Занадто ранні посіви можуть переростати, що погіршує їх перезимівлю [9]. Запізнення висіву спричиняє слабкий розвиток рослин, вони погано кущяться та потерпають від суховіїв [7].

Через розбіжність у біологічних особливостях твердих та м'яких сортів пшениці озимої рекомендації щодо строків сівби слід переглядати, особливо стосовно умов північного Степу, де це питання розглядається вперше.

Досягнення високого врожаю можливе лише за сівби по кращих попередниках [5]. Найкращим у цьому плані $\epsilon$ паровий попередник, однак реалії виробництва спонукають до підвищення рентабельності рослинництва, тому тримати пар вважається менш вигідним. Саме через це і виникає необхідність у коригуванні елементів технології за різних умов вирощування [6].

Дослідження впливу сукупності дії факторів (попередника, строку сівби та рівня мінерального живлення) може допомогти розкрити можливості отримання високого врожаю пшениці твердої озимої в умовах північного Степу.

Мета досліджень полягала у встановленні комплексного впливу попередника, рівня мінерального живлення та строків сівби на формування як зимостійкості, так і продуктивності зерна пшениці твердої озимої в умовах північного Степу.

Завданням досліджень є дослідження впливу зміни строків сівби (залежно від попередників та рівня мінерального забезпечення) на врожайність пшениці твердої озимої та формування висновків щодо кращих строків сівби залежно від умов вирощування.

Матеріали та методи досліджень. Дослідження проводились на дослідному полі навчального господарства „Самарський” Дніпровського державного аграрно-економічного університету (Дніпропетровська область) на чорноземі звичайному малогумусному середньосуглинково- 


\section{СІЛЬСЬКЕ ГОСПОДАРСТВО. РОСЛИННИЦТВО}

му. Потужність гумусованого профілю - 75 см. Вміст гумусу (за Тюріним) у верхній частині гумусо-акумулятивного горизонту становить 3,94,2\%, вміст у верхньому шарі грунту (0-20 см) азоту, що легко гідролізується (за Тюріним та Кононовою), становить 8,0-8,5 мг/100 г грунту, рухомого фосфору (за Чириковим) - 9,0-10,0 мг/100 г грунту і обмінного калію (за Масловою) - 14,0-15,0 мг/100 г грунту.

Під час проведення польових досліджень було використано загальноприйняту методику [1]. В дослідах використовували сорт пшениці твердої озимої Континент, що висівався по пару та стерньовому попереднику. Відповідно до зональних рекомендацій 3 вирощування пшениці озимої в умовах північного Степу, при порівнянні строків сівби по пару, пшениця тверда озима висівалась із нормою висіву 4,5 млн шт./га, а після стерньового попередника - 5,5 млн шт./га [8]. Дослід проводили на фоні мінеральних добрив $\mathrm{N}_{15} \mathrm{P}_{15} \mathrm{~K}_{15}$ i $\mathrm{N}_{60} \mathrm{P}_{60} \mathrm{~K}_{40}$ після стерньового попередника, та $\mathrm{P}_{15} \mathrm{i} \mathrm{N}_{30} \mathrm{P}_{60} \mathrm{~K}_{40}$ - по пару. Площа облікової ділянки - $33 \mathrm{~m}^{2}$, повторність триразова, розміщення ділянок - систематичне.

Погодні умови в роки проведення досліджень були характерними для зони Степу. Сприятли- вими для росту, розвитку і формування урожаю пшениці озимої були умови вегетації 2016/2017 р., менш сприятливими - 2014/15 і 2015/16 pp.

Результати досліджень. Найбільш розвинутими на час припинення осінньої вегетації були рослини ранніх строків сівби (табл. 1). Строк сівби суттєво вплинув на розвиток рослин. Так, зміщення строків сівби від ранніх до пізніх призводить до зниження всіх біометричних показників: висоти, маси рослин, кількості стебел i вузлових коренів. Листостеблова маса рослин після парового попередника раннього строку сівби була майже вдвічі більшою, ніж у рослин пізнього строку. Вони також мали вдвічі більше стебел і вузлових коренів. Після стерньового попередника різниця між крайніми варіантами строків сівби була незначна, але як і по пару, рослини ранніх строків сівби також були більш розвинені.

Однак перерослі рослини раннього строку сівби мають низьку стійкість до комплексу несприятливих умов зимового періоду й існує більша вірогідність їх ушкодження взимку. Рослини пізнього строку сівби з осені слабо розвиваються, що не дає їм можливості в подальшому сформувати високу зернову продуктивність.

\section{1. Стан рослин пшениці твердої озимої сорту Континент на час припинення осінньої вететації залежно від попередників та строків сівби, середнє за 2014-2016 рр.}

\begin{tabular}{|c|c|c|c|c|c|c|}
\hline \multicolumn{2}{|c|}{ Варіант } & \multirow{2}{*}{$\begin{array}{c}\text { Маса } 100 \\
\text { абсолютно } \\
\text { сухих рослин, г }\end{array}$} & \multirow[b]{2}{*}{ Висота, см } & \multicolumn{2}{|c|}{ Кількість на рослині, шт. } & \multirow{2}{*}{\begin{tabular}{|c|} 
Глибина \\
залягання \\
вузла кущен- \\
ня, см \\
\end{tabular}} \\
\hline попередник & строк сівби & & & стебел & $\begin{array}{c}\text { вузлових } \\
\text { коренів }\end{array}$ & \\
\hline \multicolumn{7}{|c|}{ Низький рівень мінерального живлення } \\
\hline \multirow{4}{*}{ Пар } & 3.09 & 21,7 & 20,6 & 2,6 & 3,2 & 2,6 \\
\hline & 10.09 & 17,7 & 20,1 & 2,3 & 1,5 & 2,8 \\
\hline & 17.09 & 14,7 & 16,9 & 1,7 & 1,0 & 2,9 \\
\hline & 24.09 & 13,1 & 16,9 & 1,5 & 1,0 & 3,6 \\
\hline \multirow{4}{*}{ Стерня } & 3.09 & 7,0 & 12,1 & 1,3 & 1,0 & 1,6 \\
\hline & 10.09 & 7,4 & 13,9 & 1,2 & 1,0 & 1,8 \\
\hline & 17.09 & 6,7 & 13,4 & 1,2 & 1,0 & 2,0 \\
\hline & 24.09 & 6,3 & 11,8 & 1,2 & 1,0 & 2,0 \\
\hline \multicolumn{7}{|c|}{ Високий рівень мінерального живлення } \\
\hline \multirow{4}{*}{ Пар } & 3.09 & 19,9 & 20,4 & 2,5 & 3,8 & 2,2 \\
\hline & 10.09 & 15,6 & 20,2 & 2,4 & 2,3 & 2,6 \\
\hline & 17.09 & 11,2 & 17,9 & 1,8 & 1,1 & 3,1 \\
\hline & 24.09 & 10,5 & 17,1 & 1,7 & 1,0 & 3,4 \\
\hline \multirow{4}{*}{ Стерня } & 3.09 & 8,7 & 15,3 & 1,4 & 1,2 & 1,7 \\
\hline & 10.09 & 10,4 & 15,0 & 1,3 & 1,2 & 1,7 \\
\hline & 17.09 & 9,9 & 14,0 & 1,4 & 1,1 & 1,8 \\
\hline & 24.09 & 8,3 & 13,0 & 1,3 & 1,0 & 1,9 \\
\hline
\end{tabular}




\section{СІЛЬСЬКЕ ГОСПОДАРСТВО. РОСЛИННИЦТВО}

На відміну від інших біометричних показників, глибина залягання вузла кущення збільшується від ранніх до пізніх строків сівби. Це пов'язано, перш за все, з поступовим зниженням температури в осінній період і більш пізньою закладкою вузла кущення рослинами пізніх строків сівби.

Мінеральні добрива вже на ранніх етапах розвитку рослин позитивно вплинули на основні біометричні показники. Рослини за збільшеної кількості мінеральних добрив інтенсивніше розвивались, накопичували більшу масу, формували більшу кількість стебел та вузлових коренів.

Різниця між рівнями мінерального живлення виразніше проявляється після стерньового попередника, так як тут спостерігається більший дефіцит елементів живлення, створений попередником. Різницю між рівнями мінерального живлення по паровому попереднику також чітко видно, однак вона менша, ніж після стерньового попередника. Отже, попередник (а точніше наявність вологи та поживних речовин) має першочергове значення для росту та розвитку рослин в умовах північного Степу.

Перезимівля - один із найважливіших етапів розвитку рослин у досягненні бажаної врожайності, а ii підвищення - ключовий напрямк розробки технології вирощування.

Більш високу зимостійкість мають рослини пізніх строків сівби. Найменш резистентними виявилися рослини ранніх строків сівби (табл. 2). У середньому за роки досліджень найбільшу витривалість до несприятливих умов зимівлі виявили рослини за сівби 17 вересня, незалежно від попередника і фона мінерального удобрення. Це може бути пояснено як низькою морозостійкістю рослин ранніх строків сівби, так і слабкою витривалістю рослин пізніх строків сівби до різного роду механічних ушкоджень.

Внесення підвищених доз мінеральних добрив позитивно вплинуло на перезимівлю рослин пшениці твердої озимої, причому по пару ефективність дії добрив була вища, ніж після стерньового попередника. Слід відмітити низький показник перезимівлі за низького рівня мінера- льного живлення після парового попередника. Це зумовлено переростанням рослин раннього строку сівби.

Враховуючи відносно складні погодні умови двох із трьох років досліджень, перезимівля на рівні 87,7-95,2 \% - це досить непоганий результат для пшениці твердої озимої в умовах північного Степу.

Високі дози внесення мінеральних добрив дещо покращують рівень виживання рослин, незалежно від строків сівби, і сприяють створенню передумов високої продуктивності. У цілому, краще збереглися рослини за умов внесення мінеральних добрив та оптимального й пізнього строків сівби. По пару рослини стабільно краще розвивались та мали більший відсоток рослин, що перезимували.

На час відновлення весняної вегетації тенденції в розвитку рослин, які було отримано з осені, збереглись, однак маса 100 рослин, кількість стебел та кількість заново утворених вузлових коренів була в 2-5 разів більшою по паровому попереднику, ніж по стерньовому (табл. 3).

Збільшення кількості мінеральних добрив позитивно вплинуло на ріст та розвиток рослини пшениці твердої озимої після стерньового попередника. По пару збільшення кількості мінеральних добрив за ранніх строків сівби зменшувало біометричні показники стану рослин. Це пов'язано $з$ переростанням рослин ранніх строків у разі збільшення кількості мінеральних добрив по пару.

Зміщення в більш пізні строки сівби спричиняло зниження всіх показників стану рослин, проте кількість заново утворених вузлових коренів після стерньового попередника була нижчою як за ранніх, так за пізніх строків сівби.

Таким чином, незважаючи на більш високу зимостійкість озимої пшениці пізніх строків сівби і найбільшу розвиненість рослин раннього строку сівби, при відновленні весняної вегетації в найбільш сприятливому стані для подальшого росту і формування максимальної продуктивності знаходяться рослини оптимального строку сівби (табл. 4).

\section{2. Перезимівля пшениці твердої озимої сорту Континент залежно від попередників та строків сівби, \% рослин, щчо збереглись, середнє за 2015-2017 рр.}

\begin{tabular}{|c|c|c|c|c|}
\hline \multirow{2}{*}{ Строк сівби } & \multicolumn{2}{|c|}{ Стерньовий попередник } & \multicolumn{2}{c|}{ Паровий попередник } \\
\cline { 2 - 5 } & $\mathrm{N}_{15} \mathrm{P}_{15} \mathrm{~K}_{15}$ & $\mathrm{~N}_{60} \mathrm{P}_{60} \mathrm{~K}_{40}$ & $\mathrm{P}_{15}$ & $\mathrm{~N}_{30} \mathrm{P}_{60} \mathrm{~K}_{40}$ \\
\hline 3.09 & 91,6 & 91,3 & 87,7 & 92,0 \\
\hline 10.09 & 91,7 & 93,9 & 92,0 & 92,5 \\
\hline 17.09 & 94,9 & 94,4 & 93,4 & 95,2 \\
\hline 24.09 & 92,2 & 93,1 & 93,8 & 94,0 \\
\hline
\end{tabular}


СІЛЬСЬКЕ ГОСПОДАРСТВО. РОСЛИННИЦТВО

3. Стан рослин пшениці твердої озимої сорту Континент на час відновлення весняної вететації залежно від попередників та строків сівби, середнє за 2015-2017 рр.

\begin{tabular}{|c|c|c|c|c|c|}
\hline \multicolumn{2}{|c|}{ Варіант } & \multirow{2}{*}{$\begin{array}{c}\text { Маса } 100 \\
\text { абсолютно сухих } \\
\text { рослин, г }\end{array}$} & \multirow{2}{*}{$\begin{array}{c}\text { Висота, } \\
\text { см }\end{array}$} & \multirow{2}{*}{$\begin{array}{c}\text { Кількість } \\
\text { стебел, шт. }\end{array}$} & \multirow{2}{*}{$\begin{array}{c}\text { Кількість заново } \\
\text { утворених вузлових } \\
\text { коренів, шт. } \\
\end{array}$} \\
\hline попередник & $\begin{array}{l}\text { строк } \\
\text { сівби }\end{array}$ & & & & \\
\hline \multicolumn{6}{|c|}{ Низький рівень мінерального живлення } \\
\hline \multirow{4}{*}{ Пар } & 3.09 & 58,7 & 23,1 & 5,7 & 5,6 \\
\hline & 10.09 & 39,9 & 22,4 & 3,1 & 3,1 \\
\hline & 17.09 & 34,6 & 21,5 & 3,0 & 2,9 \\
\hline & 24.09 & 25,0 & 19,5 & 2,5 & 1,9 \\
\hline \multirow{4}{*}{ Стерня } & 3.09 & 20,1 & 19,1 & 1,7 & 1,2 \\
\hline & 10.09 & 17,9 & 19,3 & 2,0 & 1,6 \\
\hline & 17.09 & 16,1 & 18,8 & 1,7 & 1,5 \\
\hline & 24.09 & 13,9 & 17,6 & 1,5 & 1,4 \\
\hline \multicolumn{6}{|c|}{ Високий рівень мінерального живлення } \\
\hline \multirow{4}{*}{ Пар } & 3.09 & 57,3 & 22,7 & 5,0 & 3,0 \\
\hline & 10.09 & 34,5 & 22,3 & 2,8 & 2,2 \\
\hline & 17.09 & 36,0 & 21,7 & 3,5 & 2,8 \\
\hline & 24.09 & 22,0 & 20,5 & 2,3 & 1,9 \\
\hline \multirow{4}{*}{ Стерня } & 3.09 & 25,4 & 19,5 & 2,0 & 1,5 \\
\hline & 10.09 & 26,6 & 20,1 & 2,1 & 1,7 \\
\hline & 17.09 & 22,5 & 19,6 & 1,9 & 1,5 \\
\hline & 24.09 & 16,7 & 17,6 & 1,8 & 1,4 \\
\hline
\end{tabular}

4. Урожайність пшениці твердої озимої сорту Континент залежно від попередників та строків сівби, середнс за 2014-2017 pp., m/2a

\begin{tabular}{|c|c|c|c|c|}
\hline \multirow{2}{*}{ Строк сівби } & \multicolumn{2}{|c|}{ Стерньовий попередник } & \multicolumn{2}{c|}{ Паровий попередник } \\
\cline { 2 - 5 } & $\mathrm{N}_{15} \mathrm{P}_{15} \mathrm{~K}_{15}+\mathrm{N}_{30}$ & $\mathrm{~N}_{60} \mathrm{P}_{60} \mathrm{~K}_{40}+\mathrm{N}_{30}$ & $\mathrm{P}_{15}+\mathrm{N}_{30}$ & $\mathrm{~N}_{30} \mathrm{P}_{60} \mathrm{~K}_{40}+\mathrm{N}_{30}$ \\
\hline 3.09 & 1,42 & 1,59 & 2,35 & 2,73 \\
\hline 10.09 & 2,17 & 2,31 & 2,91 & 3,21 \\
\hline 17.09 & 1,62 & 2,16 & 3,26 & 3,68 \\
\hline 24.09 & 1,61 & 1,77 & 3,05 & 3,10 \\
\hline
\end{tabular}

Таким чином, найвища урожайність у досліді була отримана за сівби пшениці твердої озимої по пару 17 вересня на фоні основного внесення $\mathrm{N}_{30} \mathrm{P}_{60} \mathrm{~K}_{40}+\mathrm{N}_{30}$ у підживлення - 3,68 т/га. За низького рівня мінерального живлення по пару краща врожайність сформувалась також за сівби 17 вересня.

Після стерньового попередника найбільша зернова продуктивність сформувалась за більш ранньому строку сівби - 10 вересня. За низького рівня мінерального живлення врожайність склала 2,17 т/га, а за високого - 2,31 т/га.

\section{Висновки:}

1. На час припинення осінньої вегетації рослини пшениці твердої озимої найбільшого розвитку набувають за раннього строку сівби (3.09) за сівби після парового попередника.

2. Найбільшу витривалість до несприятливих умов зимівлі формують рослини оптимального i пізнього строку сівби (17.09-24.09).

3. Максимальна урожайність пшениці твердої озимої по пару формується за високого рівня мінерального живлення за сівби 17 вересня, після стерньового попередника - за високого рівня мінерального живлення за сівби 10 вересня. 


\section{БІБЛІОГРАФІЯ}

1. Доспехов Б. А. Методика полевого опыта. М. : Колос, 1979. - 116 c.

2. Лазаренко П. И. Эколого-биологические основы сельскохозяйственного районирования территорий. - Днепропетровск : Пороги, 1995. $476 \mathrm{c}$.

3. Нетіс I. T. Наукове обгрунтування та розробка енергозберігаючих технологій вирощування озимої м'якої і твердої пшениці на зрошуваних землях півдня України: Автореф. дис... д-ра с.-г. наук: 06.01.09 «Рослинництво» / Херсон, 1998. - $34 \mathrm{c}$.

4. Паламарчук A. I. Методи і результати селекції твердої озимої пшениці для умов Степу та Лісостепу України / А. І. Паламарчук // Посібник українського хлібороба. - 2012. - Т. 2. - С. 168171.

5. Системи сучасних інтенсивних технологій у рослинництві : підручник / [C. М. Каленська, Л. М. Срмакова, В. Д. Паламарчук та ін.]; Нац. ун-т біоресурсів і природокористування України,

\section{ANNOTATION}

Yarchuk I. I., Mel'nyk T. V. Precursor and seeding time of flint winter wheat.

Ukraine has all weather conditions for producing high quality grain of flint winter wheat, but there still insufficiently clear recommendations on the technology of growing flint winter wheat in the conditions of the Northern Steppe of Ukraine. Therefore, it is necessary to study the influence of the main elements of cultivation technology to provide high-quality grain of the food industry.

The results of the study of influence of the seeding rate on the crop capacity of flint winter wheat after three years of testing are presented. We described the most effective measures of a flint winter wheat seeding of sort Continent in a Northern Steppe. During the three years of research, optimum seeding time have been determined for various precursors depending on the mineral nutrition level.

The largest development during the termination of autumn vegetation is acquired plants that grow after the vapor precursor at the first seeding time
Вінниц. нац. аграр. ун-т. - Вінниця : Рогальська I. О., 2015, [2] с. - Бібліогр.: с. 410-412 - укр.

6. Середа I. I. Особливості технології вирощування пшениці озимої по непарових попередниках в умовах північного Степу України / I. I. Середа // Бюлетень Інституту сільського господарства степової зони. - 2011, № 1. - С. 101106.

7. Урожайность озимой пшеницы в связи со сроками посева / Володарский Н. И., Улитин А. М., Губанов Я. В. // Озимая пшеница. - М.: Изд-во с.-х. литературы, 1967. - Вып. 1. - С. 364-391.

8. Ярошенко С. С. Формування врожаю пшениці озимої при різних технологіях вирощування залежно від норм висіву насіння / С. С. Ярошенко // Бюлетень Інституту зернового господарства, 2011. - № 40. - С. 68-72.

9. Green C. F., Fauison G. A., Ivins J. D. Time of sowing and the development of winter whiat // J. Agr. Sci. - 1985. - 105. - № 1. - P. 217-221.

when using high doses of mineral fertilizers, however, such crops are characterized by a worse overwintering.

The largest number of plants survived after overwintering is observed after the stern precursor and latest seeding time with increased level of mineral nutrition. After vapor precursor the highest level of surviving was detected on the plots with the latest seeding time.

According to the stern precursor, the maximum crop capacity of flint winter wheat is formed while seeding September 10 with high level of mineral nutrition, and after the vapor precursor the largest crop capacity is given by plants that was sown September 17 with a high level of mineral nutrition. The highest yield was formed after the vapor precursor at a high level of mineral nutrition at the sowing on September 17 and amounted to $3.68 \mathrm{t} / \mathrm{ha}$.

Key words: flint winter wheat, precursor, seeding time, growth and development, overwintering, elements of the structure of the crop, crop capacity. 